\title{
Antioxidant capacity of alcoholic beverages based on infusions from non-traditional spicy-aromatic vegetable raw materials
}

\section{Oleg Kuzmin ${ }^{1}$, Volodymyr Kucherenko², Iryna Sylka1, Volodymyr Isaienko ${ }^{3}$, Yuliia Furmanova', Olena Pavliuchenko ${ }^{1}$, Viacheslav Hubenia ${ }^{1}$}

\author{
1 - National University of Food Technologies, Kyiv, Ukraine \\ 2 - Ukrainian Corporation for Viticulture and Wine Industry "Ukrvinprom" \\ 3 - National Aviation University, Kyiv, Ukraine
}

\section{Keywords:}

Spicy-aromatic

Antioxidant

Redox

Infusion

Alcohol

\section{Article history:}

Received 01.08.2019

Received in revised form 23.12.2019

Accepted

30.06 .2020

Corresponding author:

Oleg Kuzmin

E-mail:

kuzmin_ovl@ukr.net

DOI:

$10.24263 / 2304-$

974X-2020-9-2-12

\section{Abstract}

Introduction. The aim of the study is to determine the antioxidant capacity of aqueous-alcoholic infusions using nontraditional spicy-aromatic raw materials in the technology of alcoholic beverages.

Materials and methods. Antioxidant ability of infusions of spicy-aromatic plants: Perilla frutescens; Elsholtzia stauntonii Benth; Artemisia abrotanum; Monarda didyma; Agastache foeniculum; Satureja hortensis; Ruta graveolens; Nepeta transcaucasica Grossch was determined by redoxmetry and $\mathrm{pH}-$ metry; sensory evaluation - by expert method; the results of mathematical and statistical processing - by the method of linear Pearson correlation.

Results and discussion. The minimum theoretical value of redox potential $(R P)$ for plant aqueous-alcoholic infusions was obtained, which has a value from $228.0 \mathrm{mV}$ (Satureja hortensis) to $260.4 \mathrm{mV}$ (Agastache foeniculum). The actual measured RP of infusions was established - from $117 \mathrm{mV}$ (Elsholtzia stauntonii Benth) to $134 \mathrm{mV}$ (Nepeta transcaucasica Grossch). The hydrogen index for aqueous-alcoholic infusions from spicy-aromatic raw materials has a value of 6.66 units $\mathrm{pH}$ (Agastache foeniculum) to 7.20 units $p H$ (Satureja hortensis). Aqueous-alcoholic infusions from vegetable raw materials and a volume fraction of ethanol of $40 \%$ have the value of recovery energy $(R E)$ in the range from 100.0 $\mathrm{mV}$ (Nepeta transcaucasica Grossch) to $138.2 \mathrm{mV}$ (Ruta graveolens).

Aqueous-alcoholic infusions from spicy-aromatic raw materials have values of sensory evaluation (S.e.) from 9.50 to 9.69 points. The highest value of S.e. 9.69 points is characteristic of Nepeta transcaucasica Grossch: color - light brown; taste - mint; aroma - soft, pleasant, sweet.

Conclusion. It is proposed for the technology of alcoholic beverages the use of aqueous-alcoholic infusions from Ruta Gravelens and Nepeta transcaucasica Grossch, which received increased antioxidant characteristics $R E 138.2 \mathrm{mV}$ and $R E 100.0$ $\mathrm{mV}$, respectively, and positive S.e. 9.57 and S.e. 9.69 points on a 10-point scale. 


\section{Introduction}

One of the important directions of food industry development is improvement of taste, aroma of food, preservation (or addition) of nutritional value of the final product (Dubovkina I. et al., 2019; Kuzmin et al., 2016; Kuzmin et al., 2017) [1-3].

Currently, the use of vegetable raw materials in the technology of alcoholic beverages is very relevant (Andreou et al., 2018; Chandrasekara, Shahidi, 2018; Iannitti, Palmieri, 2009; Halliwell, Gutteridge, 1990; Kawa-Rygielska et al., 2019; Fotakis et al., 2016 [4-9], especially when used in restaurant business. Herbal beverages commonly consumed worldwide contain different chemical substances that display a broad spectrum of biological activities (Kamdem et al., 2013; Frolova et al., 2019; Gerolis et al., 2017; Imark et al., 2000; Pyrzynska, Sentkowska, 2019; Wong et al., 2020; Sentkowska, Pyrzynska, 2018; Siddiqui et al., 2018; Steenkamp et al., 2004) [10-18]. They have gained growing interest among scientists and consumers due to their antioxidant properties (Breiter et al., 2011; Dube et al., 2017 [19, 20]. The ability of plant phenolics to act as free radical scavengers has led to increased interest in their ability to act as antioxidants (Keating et al., 2014; Oh et al., 2013; Herrera et al., 2018; Humia et al., 2020) [21-24]. Antioxidants are able to reduce the output of oxidation products: hydroperoxides, alcohols, aldehydes, ketones, fatty acids.

Beverages are rich sources of natural bioactive compounds such as carotenoids, phenolic acids, flavonoids, coumarins, alkaloids, polyacetylenes, saponins and terpenoids, among others (Ruiz-Ruiz et al., 2020; Naithani et al., 2006) [25, 26]. Of particular interest in the production of alcoholic beverages is a spicy-aromatic raw material that exhibits antioxidant and tonic properties (Vergun et al., 2018; Vergun et al., 2019; Kurylo et al., 2018) [27-29]. At present, the antioxidant characteristics of all prescription components, food additives, biologically active substances and their combinations have not been sufficiently studied (Buglass et al., 2012; Grunert et al., 2018; Gullón et al., 2018; Gulua et al., 2018; Joubert, Beer, 2012) [3034].

$R P$ is an important indicator of the biological activity of solutions (Kuzmin O. et al., 2016; Merwe et al., 2017) [2,35]. It characterizes the deviation from the ionic balance of free electrons in a liquid medium. Changing the concentration of free electrons leads to a change in its electron charge and, accordingly, the $R P$. If the $R P$ is positive, it indicates the oxidizing ability of the solution, negative indicates recovery ability. The value of $R P$ allows to estimate the energy of processes, that is, characterizes the activity of ions in redox reactions (Bahir, 1999; Priluckij, 1997) $[36,37]$. Therefore, in order for the human body to optimally use in the exchange processes aqueous-alcoholic mixtures and food, the $R P$ values must correspond to the $R P$ values of the internal environment of the organism, or have more negative values (Bahir, 1999) [36].

But among all the useful properties, the main thing will be to change the redox reactions (Priluckij, 1997) [37]. Redox reactions affect the ratio of energy to support homeostasis relativity of dynamic constancy of composition and properties of internal environment and stability of basic physiological functions of an organism. This ensures the vital activity of any organism. The magnitude of this rate depends on the ratio and concentration of oxidized and reduced substances in the body, including substances coming from food and beverages, so one of the main factors in the regulation of redox reactions is the redox potential (Kuzmin O. et al., 2016; Bahir, 1999; Priluckij, 1997) [2, 36, 37].

These circumstances determine the relevance of this work, which is to develop aqueousalcoholic infusions of vegetable raw materials in the technology of alcoholic cocktails for restaurants. Creating alcoholic cocktails with reduced toxicity through the introduction of spicyaromatic infusions with antioxidant properties, allows restaurant establishments to create new products, which favorably differentiates them from competitors, creating a favorable image of 
the institution, which cares for the protection of consumers.

The purpose of the work is to develop the scientific bases of antioxidant activity of aqueous-alcoholic infusions from vegetable raw materials and to identify the most promising plants as sources of natural antioxidants in the creation of alcoholic beverages.

It is necessary to solve the following problems:

- To substantiate the prospect of using aqueous-alcoholic infusions from vegetable raw materials in the production of alcoholic beverages;

- To establish the value of the restorative capacity of aqueous-alcoholic infusions from vegetable raw materials;

- To develop statistics on the frequency of values in a certain range of the data obtained during sensory evaluation and physicochemical values;

- To carry out mathematical and statistical analysis of indicators of aqueous-alcoholic infusions and establish internal correlation;

- Identify the most promising sources of natural antioxidants for use in alcoholic beverage technology.

\section{Materials and methods}

\section{Materials}

The study used plant raw materials that are allowed to be used in the production of alcoholic beverages. In the M.M. Gryshko National Botanic Garden of NAS of Ukraine was created new cultures of spicy-aromatic plants, which became the subject of these studies (Rakhmetov, 2011) [38].

In the Figure 1 shows a photo of vegetable raw materials: Perilla frutescens; Elsholtzia stauntonii Benth; Artemisia abrotanum; Monarda didyma; Agastache foeniculum; Satureja hortensis; Ruta graveolens; Nepeta transcaucasica Grossch. For preparation of extracts used the following basic raw materials: ethanol rectified, water, cardboard filtering.

The extracts should meet the requirements on sensory evaluation (Table 1). The extracts must meet the requirements by physicochemical parameters (Table 2).

Table 1

\section{Sensory evaluation of extract}

\begin{tabular}{|l|l|}
\hline \multicolumn{1}{|c|}{ Indicator } & \multicolumn{1}{c|}{ Characteristic } \\
\hline Appearance & $\begin{array}{l}\text { Transparent without sediment and foreign impurities fluid, acceptable } \\
\text { opalescence that disappears after filtration }\end{array}$ \\
\hline $\begin{array}{l}\text { Color, taste, } \\
\text { aroma }\end{array}$ & $\begin{array}{l}\text { The inherent vegetable raw materials from which they are made, } \\
\text { without the foreign taste and odor }\end{array}$ \\
\hline
\end{tabular}

Table 2

Physicochemical parameters of extract

\begin{tabular}{|l|c|}
\hline \multicolumn{1}{|c|}{ Parameter } & Norm \\
\hline Ethyl alcohol by volume, $\%$ & $20.0-90.0$ \\
\hline Mass fraction of essential oil, $\%$ & $0.0-15.0$ \\
\hline Mass concentration of the total extract, $\mathrm{g} / 100 \mathrm{~cm}^{3}$ & $0.1-20.0$ \\
\hline
\end{tabular}




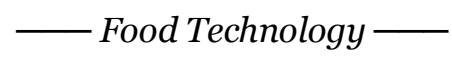

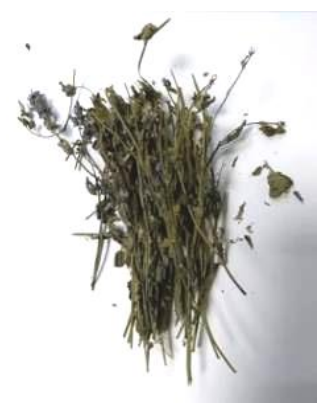

a

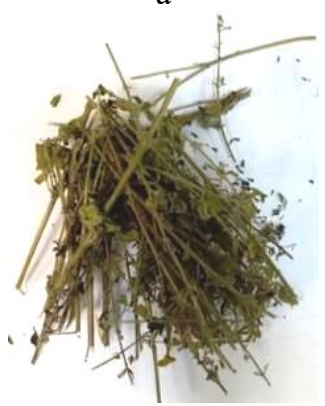

d

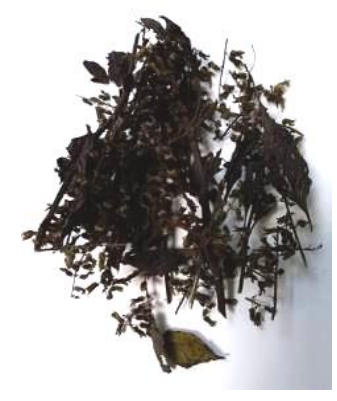

g

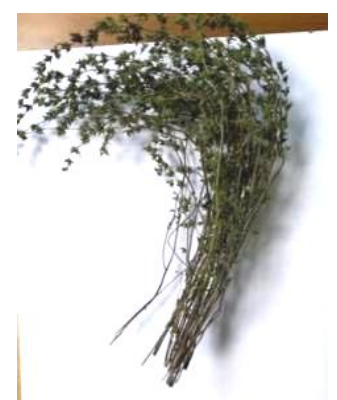

$\mathrm{b}$

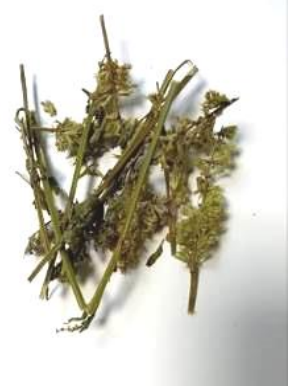

$\mathrm{e}$

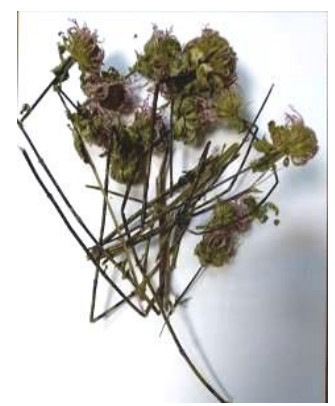

c

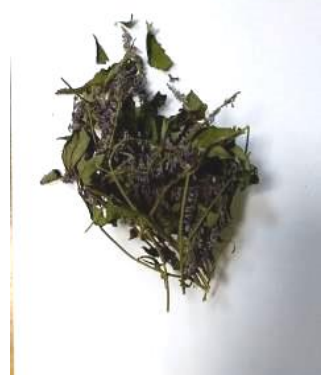

f

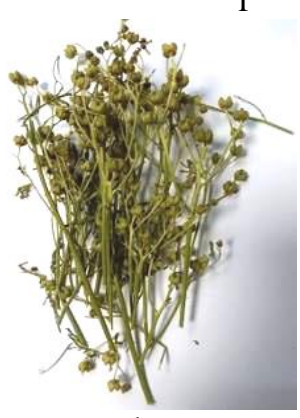

$\mathrm{h}$

Figure 1. Photo of vegetable raw materials:

$\mathrm{a}-$ Perilla frutescens $; \mathrm{b}-$ Elsholtzia stauntonii Benth $; \mathrm{c}-$ Artemisia abrotanum $; \mathrm{d}-$ Monarda didyma; $\mathrm{e}$-Agastache foeniculum; $\mathrm{f}$ - Satureja hortensis; $\mathrm{g}$ - Ruta graveolens; $\mathrm{h}$ - Nepeta transcaucasica Grossch

Aqueous-alcoholic infusion - semi-finished product, which is prepared by extraction of raw materials in aqueous-alcoholic solution with a strength of $40 \%$. The static method of extraction is called maceration. The tested aromatic raw material (dry) was infused in a aqueous-alcoholic mixture in this work.

\section{Description of research procedure}

The first stage - the preparation of infusions. Plant raw materials were minced into a size of $3 \times 3 \mathrm{~mm}$ (Figure 2), suspensions of $4 \mathrm{~g}$ were placed into the glass bottles, were filled by $100 \mathrm{ml}$ of alcohol solvent with volume fraction of rectified ethyl alcohol $40 \%$. The resulting infusions were cooled to $20^{\circ} \mathrm{C}$ for 7 days, stirring periodically. 


\section{— Food Technology}

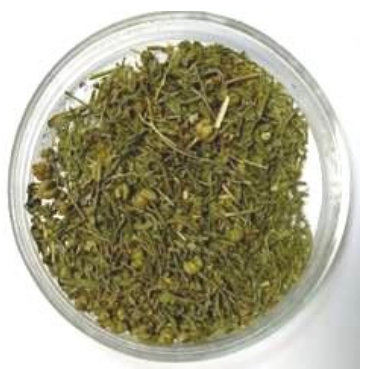

a

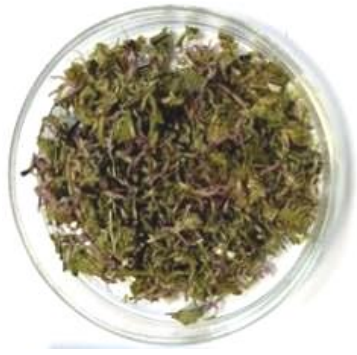

d

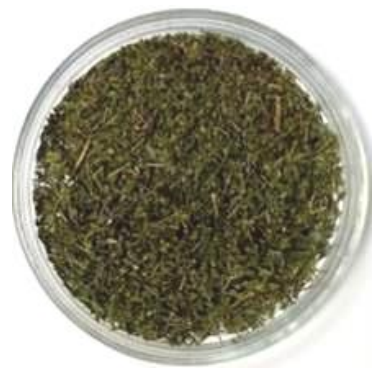

g

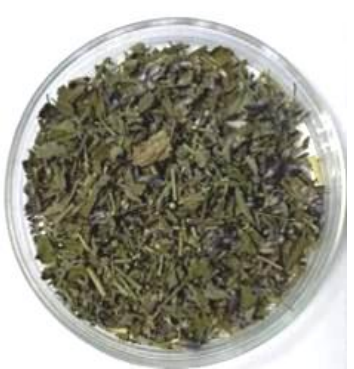

$\mathrm{b}$

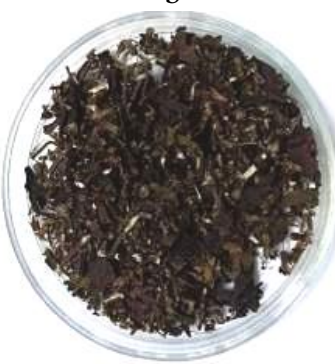

e

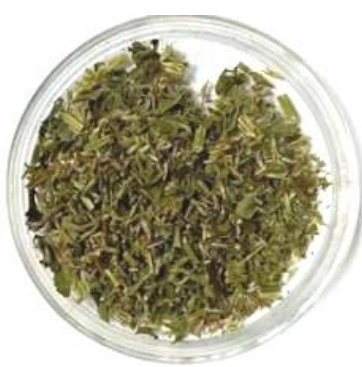

C

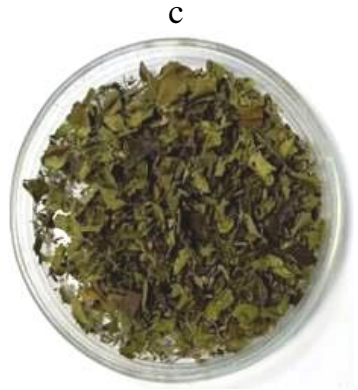

$\mathrm{f}$

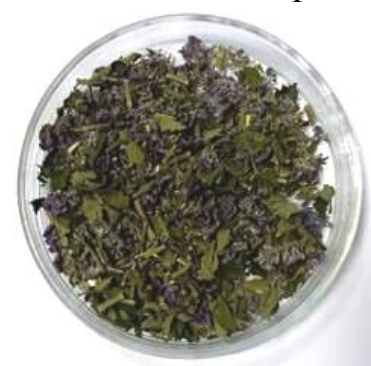

$\mathrm{h}$

Figure 2. Photo of Samples of crushed plant raw materials:

$\mathrm{a}-$ Perilla frutescens; $\mathrm{b}-$ Elsholtzia stauntonii Benth; $\mathrm{c}-$ Artemisia abrotanum $; \mathrm{d}-$ Monarda didyma; $\mathrm{e}$-Agastache foeniculum; $\mathrm{f}$ - Satureja hortensis; $\mathrm{g}$ - Ruta graveolens; $\mathrm{h}$ - Nepeta transcaucasica Grossch.

Next, the infusions were filtered and studies were performed to determine the indicators of active acidity, which was measured on a $\mathrm{pH}$ meter in the mode of $\mathrm{pH}$ measurement with a combined glass electrode. The $R P$ was measured in the potential measurement mode with a combined redoxmetric platinum electrode.

\section{Description of methods}

Expert method of sensory evaluation. The expert method of determination of values of indexes of quality is based on the account of opinions of group highly skilled specialistsexperts. (The expert of - it a specialist on the certain type of object which owns the increased sensitiveness to properties of this object) (Kuzmin et al., 2016; Kuzmin et al., 2017) [2, 3]. 
Methods for determining antioxidant capacity. To evaluate the antioxidant properties of the obtained aqueous-alcoholic plant infusions, the method (Priluckij, 1997) [37], based on the difference of $R P$ in inactivated inorganic solutions and complex biochemical media. The main criteria of this method were its clarity, simplicity, specificity, reproducibility of results and efficiency. A number of researchers also emphasize that method allows to determine the total antioxidant activity of liquid products, including in total in a complex mixture, and multifunctional antioxidants (Kuzmin et al., 2016) [2].

Formula (1) holds for inactivated inorganic solutions in equilibrium. This formula links the active acidity of the $p H$ and the $R P$ (Priluckij, 1997) [37]:

$$
E h_{\min }=660-60 \cdot p H, \mathrm{mV}
$$

where $E h_{\min }$ - the minimum theoretically expected value of the $R P$;

$p H-$ active acidity of the test solution.

Acquired $R P$ values were compared with actual measurements of $E h_{a c t}$ solution. The change of the $R P$ toward the recovery energy $(R E)$ was determined by the formula:

$$
R E=E h_{\text {min }}-E h_{a c t}, \mathrm{mV}
$$

where $R E$ - the shift of $R P$ to the side of recovered meanings (resilence);

$E h_{\text {min }}-$ minimal theoretically expected meaning of $R P$;

$E h_{\text {act }}$ - actual measured $R P$.

Mathematical and statistical methods. Pearson correlation coefficient measures the strength of the linear association between variables. Each variable should be continuous, random sample and approximately normally distributed. There are many rules of thumb on how to interpret a correlation coefficient, but all of them are domain specific. For example, here is correlation coefficient (Table 3 ) interpretation for behavioral sciences offered by Hinkle et al., 2003 [39].

Correlation coefficient interpretation

Table 3

\begin{tabular}{|c|c|}
\hline Absolute value of coefficient $(\boldsymbol{r})$ & Strength of correlation \\
\hline $0.90-1.00$ & Very high \\
\hline $0.70-0.90$ & High \\
\hline $0.50-0.70$ & Moderate \\
\hline $0.30-0.50$ & Low \\
\hline $0.00-0.30$ & Little, if any \\
\hline
\end{tabular}

The correlation coefficient can take a range of values from +1 to -1 . Positive correlation coefficient means that if one variable gets bigger, the other variable also gets bigger, so they tend to move in the same direction. Negative correlation coefficient means that the variables tend to move in the opposite directions: If one variable increases, the other variable decreases, and vice-versa. When correlation coefficient is close to zero two variables have no linear relationship (Hinkle et al., 2003; Shendrik et al., 2019) [39, 40]. 


\section{Results and discussions}

\section{Sensory evaluation}

The results of sensory evaluation (Kuzmin et al., 2017) [3] of the obtained infusions on the extractant are presented in the Table 4 and Figures 3.

Sensory evaluation (S.e.) of extracts

Table 4

\begin{tabular}{|c|c|c|c|c|}
\hline Plant raw materials & Color & Aroma & Test & $\begin{array}{l}\text { S.e., } \\
\text { points }\end{array}$ \\
\hline 1. Perilla frutescens & Light amber & Floral & $\begin{array}{c}\text { Sour-bitter, tart, } \\
\text { unpleasant }\end{array}$ & 9.50 \\
\hline $\begin{array}{l}\text { 2. Elsholtzia stauntonii } \\
\text { Benth }\end{array}$ & Light brown & Grassy, floral & Sour-bitter & 9.64 \\
\hline 3. Artemisia abrotanum & Thatched & Grassy & $\begin{array}{c}\text { Bitter, with a long, bitter } \\
\text { aftertaste }\end{array}$ & 9.51 \\
\hline 4. Monarda didyma & Thatched & Fragrant, floral & $\begin{array}{l}\text { Sour-bitter, unpleasant, } \\
\text { with a bitter aftertaste }\end{array}$ & 9.52 \\
\hline $\begin{array}{l}\text { 5. Agastache } \\
\text { foeniculum }\end{array}$ & Light amber & $\begin{array}{l}\text { Bright ethereal, } \\
\text { herbal, fragrant }\end{array}$ & Bitter, tart & 9.65 \\
\hline 6. Satureja hortensis & Light brown & $\begin{array}{l}\text { Spicy, fragrant, } \\
\text { herbal }\end{array}$ & $\begin{array}{c}\text { Moderately hot, irritable, } \\
\text { with a sweet taste }\end{array}$ & 9.67 \\
\hline 7. Ruta graveolens & Thatched & $\begin{array}{l}\text { Fragrant, } \\
\text { grassy, floral }\end{array}$ & Bitter, tart & 9.57 \\
\hline $\begin{array}{c}\text { 8. Nepeta } \\
\text { transcaucasica Grossch }\end{array}$ & Light brown & Mint & Soft, pleasant, sweet & 9.69 \\
\hline $\begin{array}{l}\text { 9. Extractant - aqueous- } \\
\text { alcoholic mixture }\end{array}$ & Transparent & Alcoholly & Abrupt & 9.57 \\
\hline
\end{tabular}

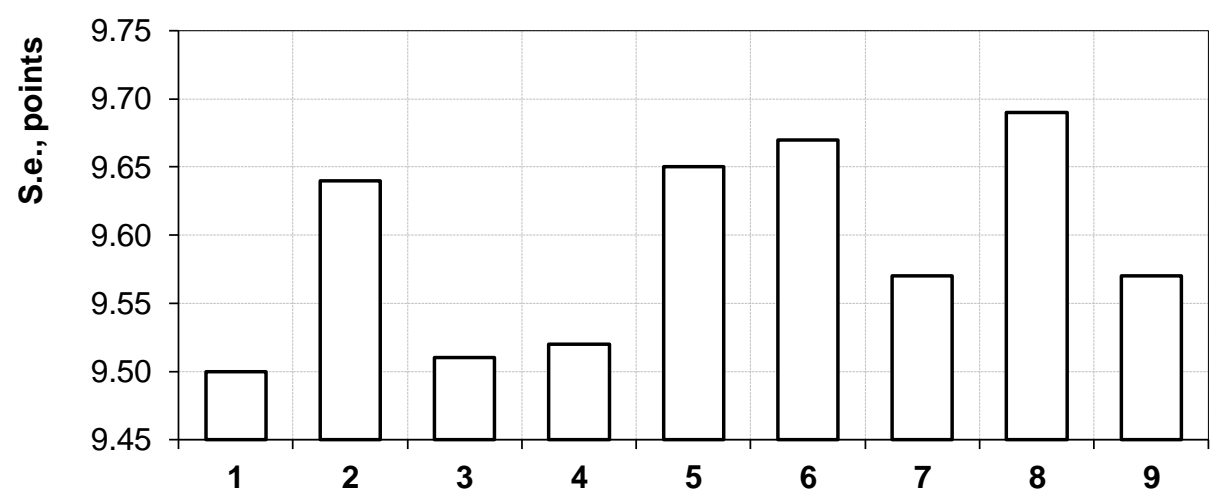

Figure 3. Sensory evaluation indicators of extracts on the extractant:

1 - Perilla frutescens; 2 - Elsholtzia stauntonii Benth; 3 - Artemisia abrotanum;

4 - Monarda didyma; 5 - Agastache foeniculum; 6 - Satureja hortensis;

7 - Ruta graveolens; 8 - Nepeta transcaucasica Grossch; 9 - aqueous-alcoholic mixture 


\section{Antioxidant capacity}

Physicochemical studies, namely determination of the $p H$ level and $R P$ (Prévost, BrilletViel, 2014; Nicoli et al., 2004) [41, 42], were performed according to the method (Priluckij, 1997) [37] and calculations given above (Kuzmin et al., 2016) [2]. As a result of extraction received infusions (Andreou et al., 2018; Chandrasekara, Shahidi, 2018; Iannitti, Palmieri, 2009; Halliwell, Gutteridge, 1990; Kawa-Rygielska et al., 2019) [4-8], physicochemical indicators (Breiter et al., 2011; Dube et al., 2017 [19, 20] of which are presented in the Table 5 .

Table 5

\section{Quality indicators of extracts on extractant}

\begin{tabular}{|c|c|c|c|c|c|}
\hline Plant raw materials & $\boldsymbol{t}^{\mathbf{0}} \mathbf{C}$ & $\boldsymbol{p H}$ & $E h_{\min }, \mathbf{m V}$ & $E h_{a c t}, \mathbf{m V}$ & $R E, \mathbf{m V}$ \\
\hline 1. Perilla frutescens & 18 & 7.07 & 235.8 & 123 & 112.8 \\
\hline 2. Elsholtzia stauntonii Benth & 17 & 7.04 & 237.6 & 117 & 120.6 \\
\hline 3. Artemisia abrotanum & 16 & 7.18 & 229.2 & 118 & 111.2 \\
\hline 4. Monarda didyma & 17 & 6.79 & 252.6 & 132 & 120.6 \\
\hline 5. Agastache foeniculum & 17 & 6.66 & 260.4 & 132 & 128.4 \\
\hline 6. Satureja hortensis & 17 & 7.20 & 228.0 & 125 & 103.0 \\
\hline 7. Ruta graveolens & 16 & 6.73 & 256.2 & 118 & 138.2 \\
\hline $\begin{array}{c}\text { 8. Nepeta transcaucasica } \\
\text { Grossch }\end{array}$ & 19 & 7.10 & 234.0 & 134 & 100.0 \\
\hline 9. Aqueous-alcoholic mixture & 18 & 7.96 & 182.4 & 180 & 2.4 \\
\hline min & $\mathbf{1 6}$ & $\mathbf{6 . 6 6}$ & $\mathbf{2 2 8 . 0}$ & $\mathbf{1 1 7}$ & $\mathbf{1 0 0 . 0}$ \\
\hline max & $\mathbf{1 9}$ & $\mathbf{7 . 2 0}$ & $\mathbf{2 6 0 . 4}$ & $\mathbf{1 3 4}$ & $\mathbf{1 3 8 . 2}$ \\
\hline
\end{tabular}

where: $t$ - temperature of infusion; $p H$ - active acidity of the test solution; $E h_{\min }$ - minimal theoretically expected meaning of $R P ;$ Ehact - actual measured $R P ; R E$ - recovery energy

Figures 4-7 show graphically the change in the physicochemical indicators of the quality of extracts of spicy-aromatic raw materials on the extractant.

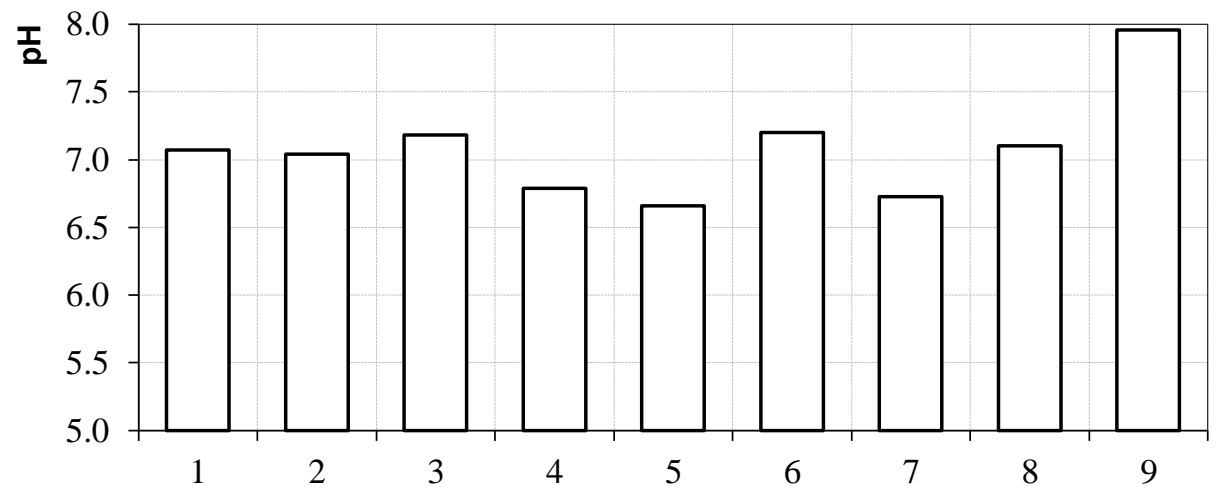

Figure 4. Hydrogen index $(\mathrm{pH})$ of infusions of the investigated raw material:

1 - Perilla frutescens; 2 - Elsholtzia stauntonii Benth; 3 - Artemisia abrotanum;

4 - Monarda didyma; 5 - Agastache foeniculum; 6 - Satureja hortensis; 7 - Ruta graveolens; 8 - Nepeta transcaucasica Grossch; 9 - Aqueous-alcoholic mixture 


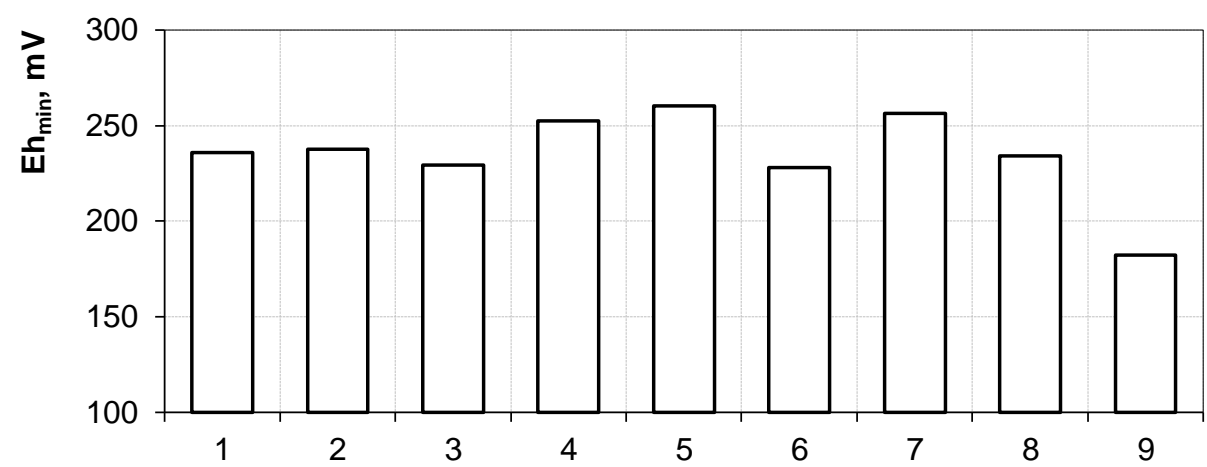

Figure 5. The minimum theoretical value of $\mathbf{R P}\left(\mathrm{Eh}_{\min }\right)$ of infusions of the investigated raw material

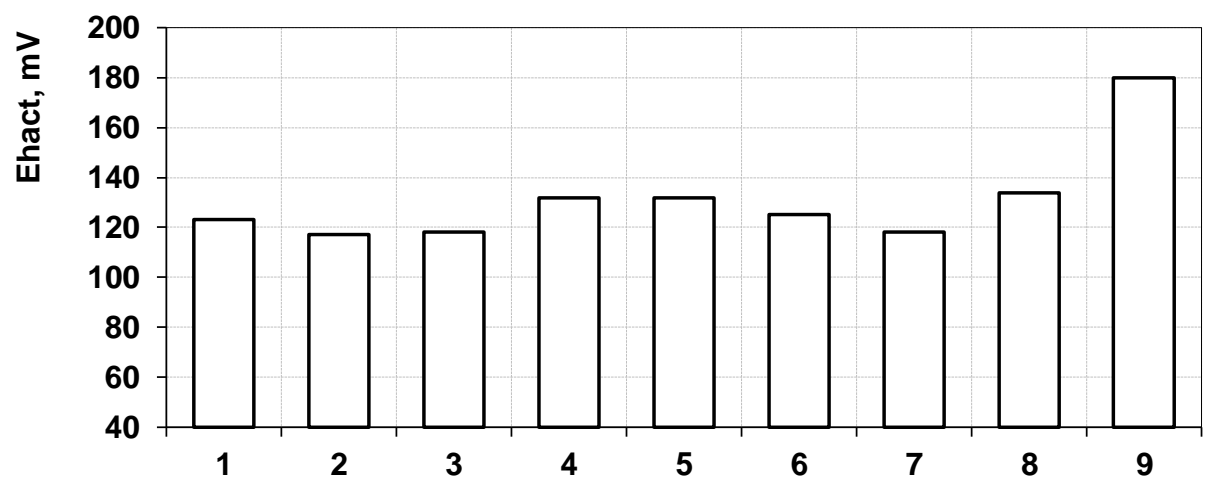

Figure 6. The actual measured $R P$ of infusions $\left(E h_{a c t}\right)$ of infusions of the investigated raw material

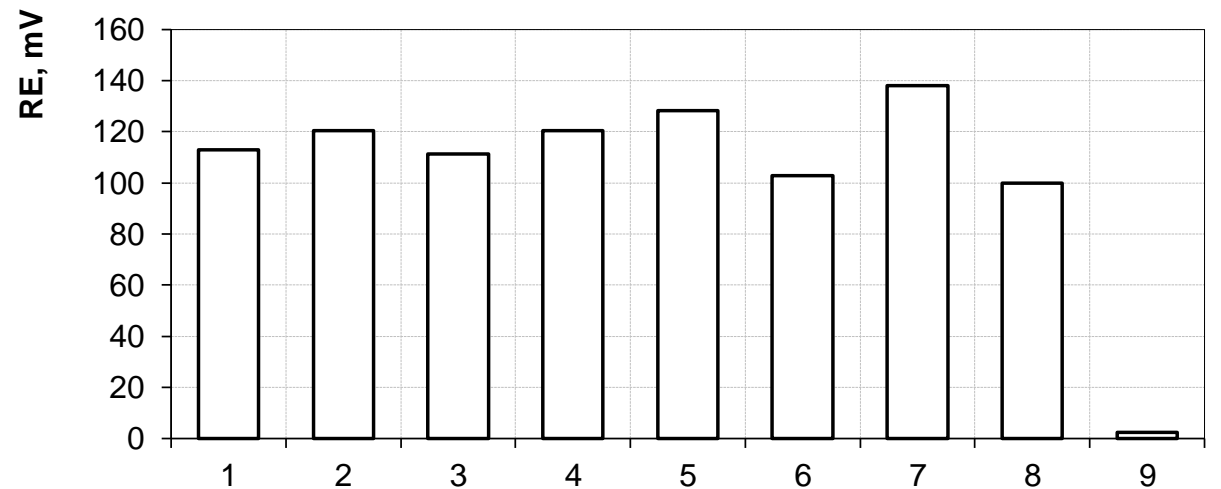

Figure 7. Recovery energy (RE) of infusions of the investigated raw material

For Figures 5-6: 1 - Perilla frutescens; 2 - Elsholtzia stauntonii Benth; 3 - Artemisia abrotanum; 4 - Monarda didyma; 5 - Agastache foeniculum; 6 - Satureja hortensis; 7 - Ruta graveolens; 8 - Nepeta transcaucasica Grossch; 9 - Aqueous-alcoholic mixture 
The minimum theoretical value of $R P\left(E h_{\min }\right)$ for plant aqueous-alcoholic infusions (Priluckij, 1997) [37] was obtained, which has a value from $228.0 \mathrm{mV}$ (Satureja hortensis) to $260.4 \mathrm{mV}$ (Agastache foeniculum). The actual measured $R P$ of infusions $\left(E h_{\text {act }}\right.$ ) was established - from $117 \mathrm{mV}$ (Elsholtzia stauntonii Benth) to $134 \mathrm{mV}$ (Nepeta transcaucasica Grossch). The hydrogen index for aqueous-alcoholic infusions from spicy-aromatic raw materials has a value of 6.66 units $p H$ (Agastache foeniculum) to 7.20 units $p H$ (Satureja hortensis).

Aqueous-alcoholic infusions from vegetable raw materials and a volume fraction of ethanol of $40 \%$ have the value of regenerative capacity (recovery energy $-R E$ ) in the range from $R E 100.0 \mathrm{mV}$ (Nepeta transcaucasica Grossch) to RE $138.2 \mathrm{mV}$ (Ruta graveolens). For the restaurant business in the manufacture of alcoholic beverages are promising aqueousalcoholic infusions of Ruta Gravelens and Nepeta transcaucasica Grossch, which received increased antioxidant characteristics $R E 138.2 \mathrm{mV}$ and $R E 100.0 \mathrm{mV}$, respectively, and positive sensory evaluation (S.e.) 9.57 and S.e. 9.69 points.

The prescription composition of alcoholic beverages may include aqueous-alcoholic infusions with a mass fraction of extractives - up to $60 \mathrm{~g} / 100 \mathrm{~cm}^{3}$ (liqueur).

\section{Determination of Pearson's linear correlation}

According to the physicochemical and sensory evaluation, mathematical and statistical analysis (Hinkle et al., 2003; Shendrik et al., 2019) [39, 40] was performed in the Pearson correlation matrix (Table 6).

Marked correlations $(r)$ are significant at $p<0,05 ; N=9$

Table 6

\begin{tabular}{|l|c|c|c|c|c|c|}
\hline & $\boldsymbol{t}$ & $\boldsymbol{p H}$ & $\boldsymbol{E h}_{\text {min }}$ & $\boldsymbol{E h}_{\text {act }}$ & $\boldsymbol{R E}$ & S.e. \\
\hline$t$ & 1,00 & 0,40 & $-0,40$ & 0,48 & $-0,46$ & 0,30 \\
\hline$p H$ & 0,39 & 1,00 & $\mathbf{- 1 , 0 0}$ & $\mathbf{0 , 7 6}$ & $\mathbf{- 0 , 9 5}$ & $-0,06$ \\
\hline$E h_{\text {min }}$ & $-0,39$ & $\mathbf{- 1 , 0 0}$ & 1,00 & $\mathbf{- 0 , 7 6}$ & $\mathbf{0 , 9 5}$ & 0,06 \\
\hline$E h_{\text {act }}$ & 0,48 & $\mathbf{0 , 8 0}$ & $\mathbf{- 0 , 8 0}$ & 1,00 & $\mathbf{- 0 , 9 3}$ & 0,01 \\
\hline$R E$ & $-0,46$ & $\mathbf{- 0 , 9 0}$ & $\mathbf{0 , 9 0}$ & $\mathbf{- 0 , 9 3}$ & 1,00 & 0,03 \\
\hline S.e. & 0,30 & $-0,10$ & 0,10 & 0,01 & 0,03 & 1,00 \\
\hline
\end{tabular}

where: $t$ - temperature of infusion; $p H$ - active acidity of the test solution; $E h_{\min }$ - minimal theoretically expected meaning of $R P ; E h_{a c t}$ - actual measured $R P ; R E$ - recovery energy; S.e. - sensory evaluation

According to the obtained matrix $6 * 6$, it was found that of the 6 indicators $\left(t, p H, E h_{\min }\right.$, $\left.E_{\text {hact }}, R E, S . e.\right)$, only 4 indicators are statistically significant. As a result of research it was found that physicochemical parameters $\left(t, p H, E h_{\min }, E h_{a c t}, R E\right)$ are statistically insignificant for sensory evaluation (S.e.), because the correlation coefficient is very weak $(r=0.0-0.3)$. Also, a weak $(r=0.3-0.5)$ and very weak $(r=0.0-0.3)$ relationship is observed between temperature $(t)$ and other physicochemical and sensory evaluation. The range of values with very high correlation ( $r=0.9-1.0)$ includes the following indicators: $p H, E h_{\text {min }}, E_{\text {hact }}, R E$.

Figure 8 shows the graphical dependence of $p H$ on $E h_{\min }$. It was found that the $p H$ is in the range of 6.66-7.96, and $E h_{\min } 182.4-260.4 \mathrm{mV}$. According to the obtained equation, at a $p H$ value of $7.00 E h_{\text {min }}$ is $240 \mathrm{mV}$. When the $p H$ value changes by $1(p H 8.00)$, the $E h_{\text {min }}$ decreases by $60 \mathrm{mV}\left(E h_{\min } 180 \mathrm{mV}\right)$. That is, the relationship between $E h_{\min }$ and $p H$ is very high, because $r=-1$, because it is inversely correlated, which leads to an increase in $p H$ to a 
decrease in the level of $E h_{\min }$. Based on the research, it was found that the addition to the aqueous-alcoholic system with a weakly alkaline environment of vegetable spicy-aromatic raw materials, which leads to acidification and reduction of the $p H$ level in the neutral environment ( $p H$ 6.66-7.20).

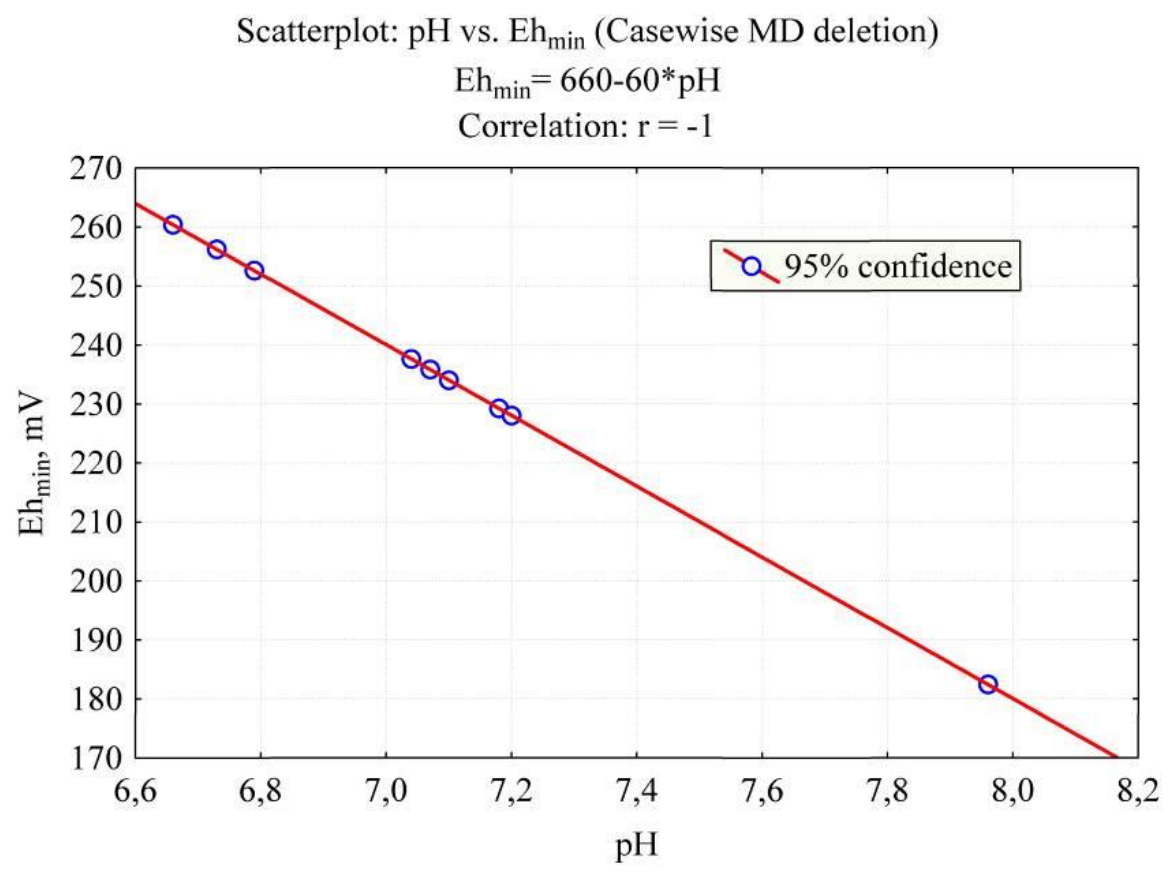

Figure 8. Dependence of $p H$ level on the $R P\left(E h_{\text {min }}\right)$

Figures 9-13 show the graphical dependence of the $p H$ level, $E h_{a c t}, E h_{\min }, R E$.

It was found that $E h_{a c t}$ is in the range from 117 to $180 \mathrm{mV}$, and the $p H$ is 6.66-7.96. At the value of $E h_{a c t} 120 \mathrm{mV}$, the $p H$ level is 6.8. If you increase the $p H$ to by one to 7.8 then the value of $E h_{\text {act }}$ will be $159 \mathrm{mV}$, i.e. $E h_{\text {act }}$ will increase by $39 \mathrm{mV}$. This is due to the fact that there is a very strong interdependence between the variables $E h_{a c t}$ and $p H(r=0.8)$. As the $p H$ value increases, the $E h_{a c t}$ index increases.

It was found that $R E$ is in the range from 2.4 to $138.2 \mathrm{mV}$, and the $p H$ is 6.66-7.96. When the value of $R E 132 \mathrm{mV}$, the $p H$ level is 6.8 . If you increase the $p H$ by one to 7.8 , the value of $R E$ will be $32 \mathrm{mV}$. Increasing the $p H$ per unit from 6.8 to 7.8 leads to a decrease in $R E$ by $100 \mathrm{mV}$. This is due to the fact that there is a very strong interdependence between the variables $R E$ and $p H(r=-0.9)$. As the $p H$ value increases, the $R E$ decreases. 
Scatterplot: $\mathrm{pH}$ vs. $\mathrm{Eh}_{\text {act }}$ (Casewise MD deletion)

$\mathrm{Eh}_{\mathrm{act}}=-142,0+38,6 * \mathrm{pH}$

Correlation: $r=0,8$

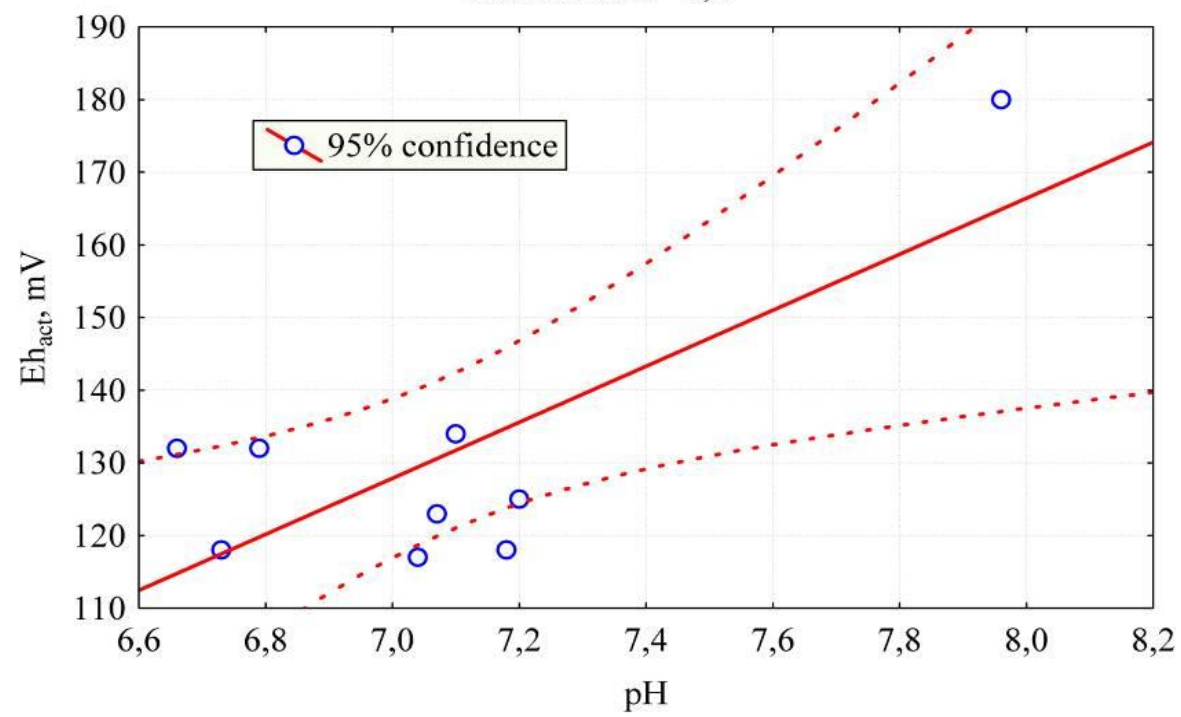

Figure 9. Dependence of $p H$ level on the $R P\left(E h_{a c t}\right)$

Scatterplot: $\mathrm{pH}$ vs. $\mathrm{RE}$ (Casewise MD deletion) $\mathrm{RE}=801,98-98,55^{*} \mathrm{pH}$

Correlation: $r=-0,9$

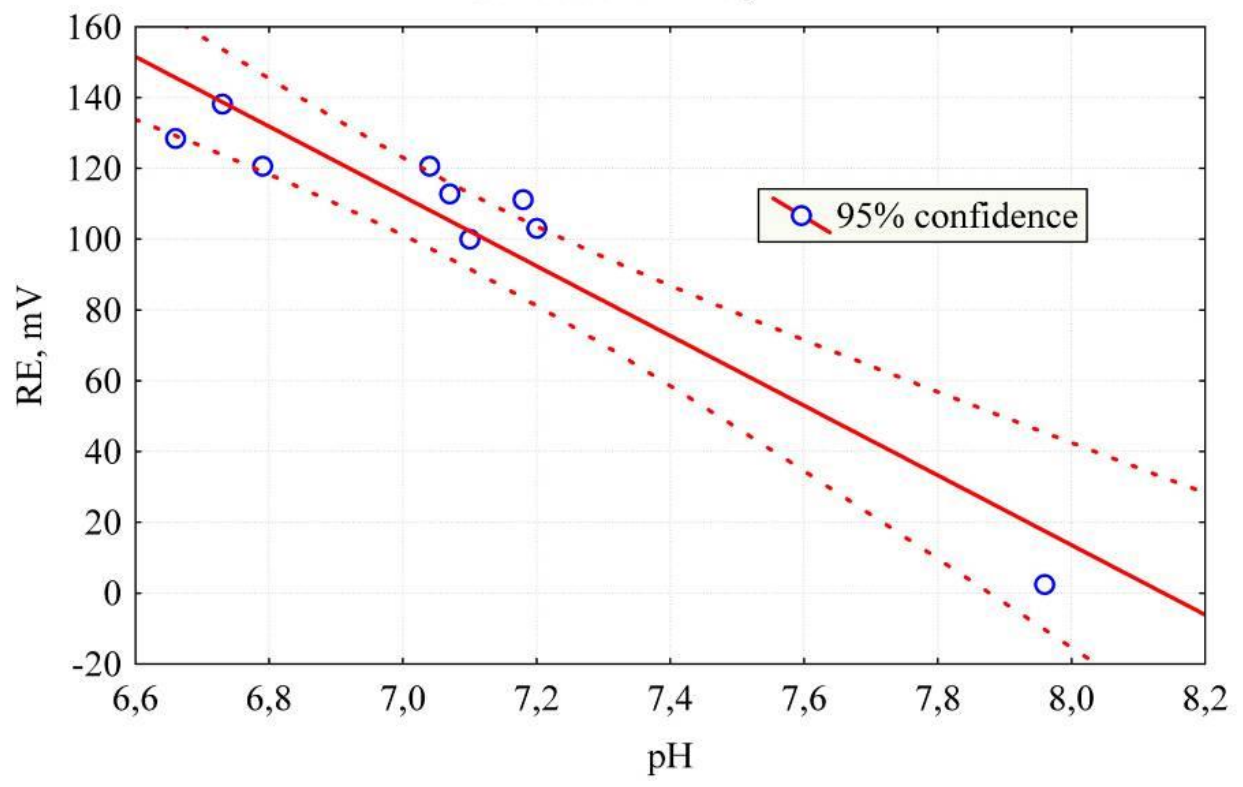

Figure 10. Dependence of $p H$ level on reduction energy $(R E)$ 
Scatterplot: $\mathrm{Eh}_{\min }$ Vs. Eh $\mathrm{Cht}_{\text {act }}$ (Casewise MD deletion)

$$
\mathrm{Eh}_{\text {act }}=282,08-0,64 * \mathrm{Eh}_{\text {min }}
$$

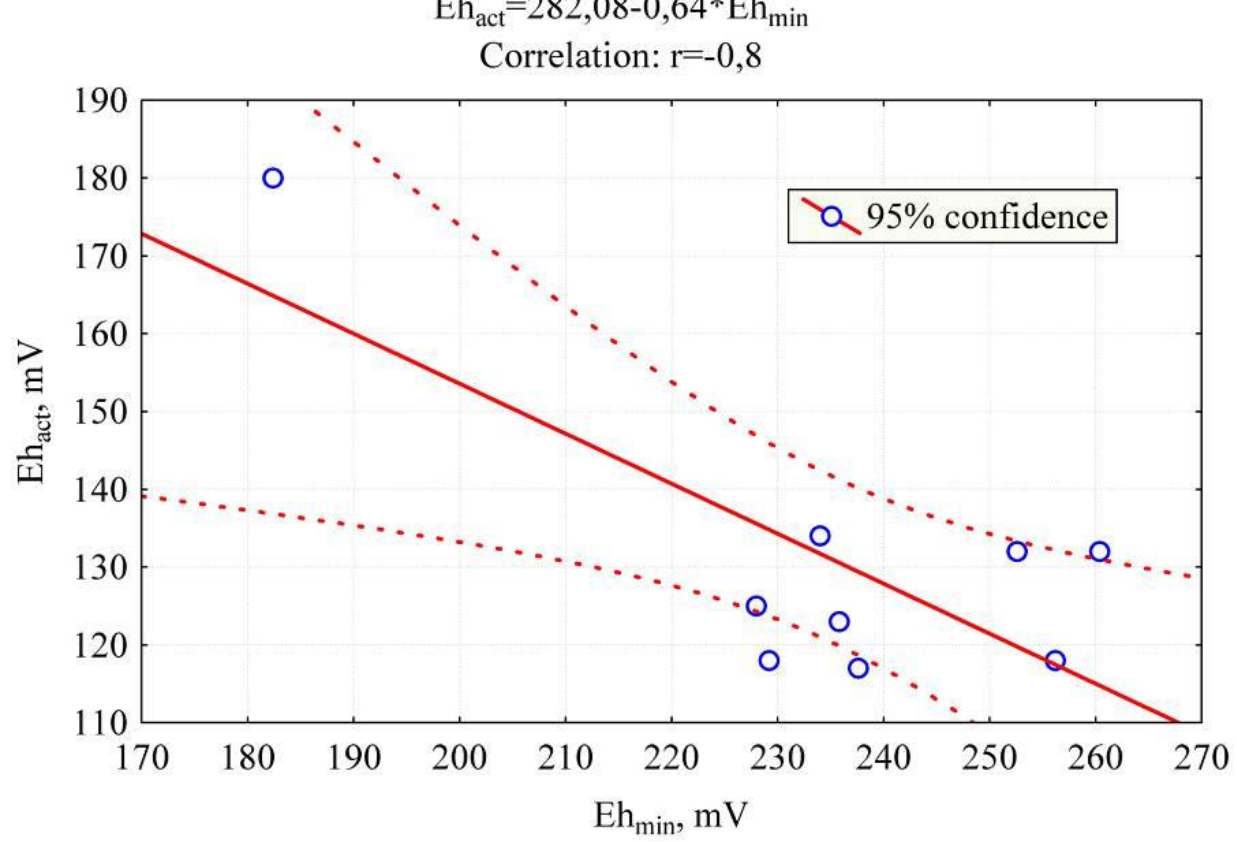

Figure 11. Dependence of $R P\left(E h_{\text {min }}\right)$ on $R P\left(E h_{a c t}\right)$

Scatterplot: $\mathrm{Eh}_{\min }$ vs. RE (Casewise MD deletion)

$\mathrm{RE}=-282,1+1,6^{*} \mathrm{Eh}_{\min }$

Correlation: $r=0,9$

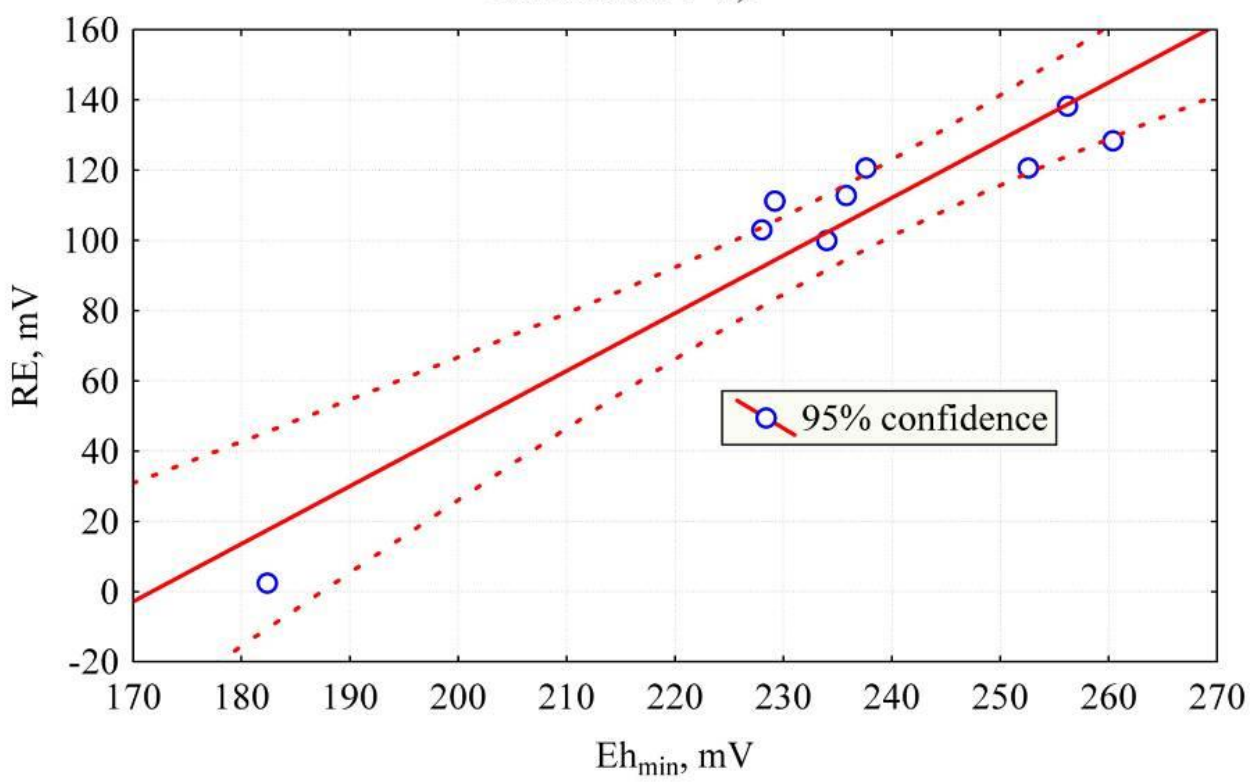

Figure 12. Dependence of $R P\left(E h_{m i n}\right)$ on reduction energy $(R E)$ 
Scatterplot: $E h_{\text {act }}$ vs. RE (Casewise MD deletion)

$\mathrm{RE}=352,90-1,90 * \mathrm{Eh}_{\text {act }}$

Correlation: $\mathrm{r}=-0,9$

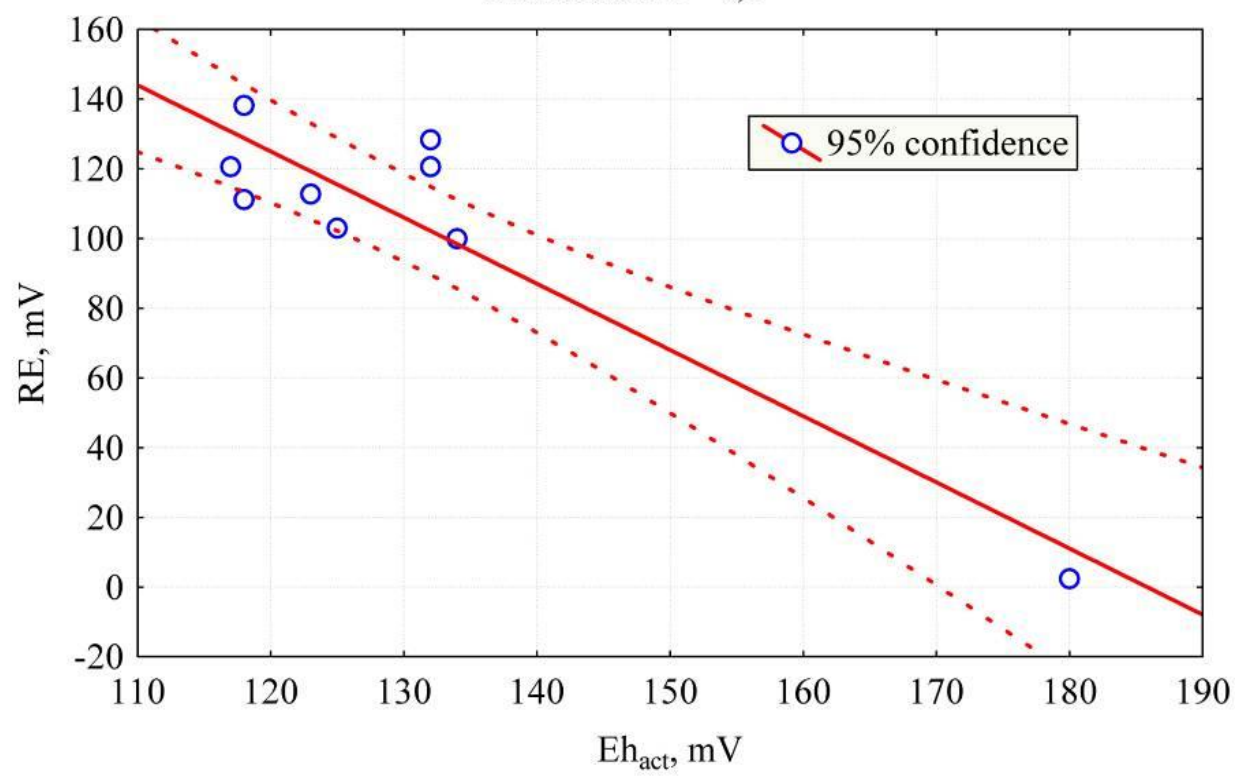

Figure 13. Dependence of $R P\left(E h_{a c t}\right)$ on reduction energy $(R E)$

The general graph of the three most correlation-significant physicochemical parameters is shown in Figure 14. In volumetric form, it is seen that some points $\left(E h_{a c t}, R E, E h_{\min }\right)$ are as close as possible to the surface, i.e. there is a very strong correlation between them. The farther the points are from the surface, the weaker the relationship.

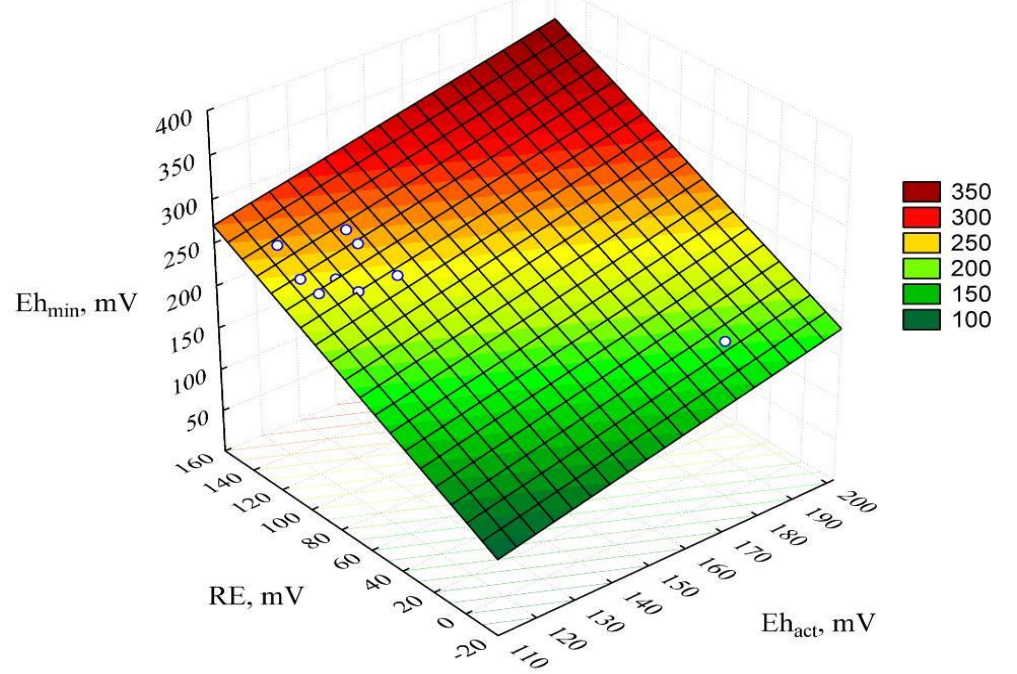

Figure 14. Response surface of $R P\left(E h_{\text {act }}\right)$ from reduction energy $(R E)$ and $R P\left(E h_{\text {min }}\right)$ 
Figures 15-19 show graphs with histograms that show the frequency of variable values in individual intervals. The histogram visually represents the distribution of a continuous numerical variable, which measures the frequency of occurrence of similar values in the data set. The $\mathrm{x}$-axis shows the numerical values, which are divided into ranges. Each range corresponds to a column of the histogram; the width of the column corresponds to the value of the interval, and the height is the number of elements in the data set, the values of which fall into this interval.

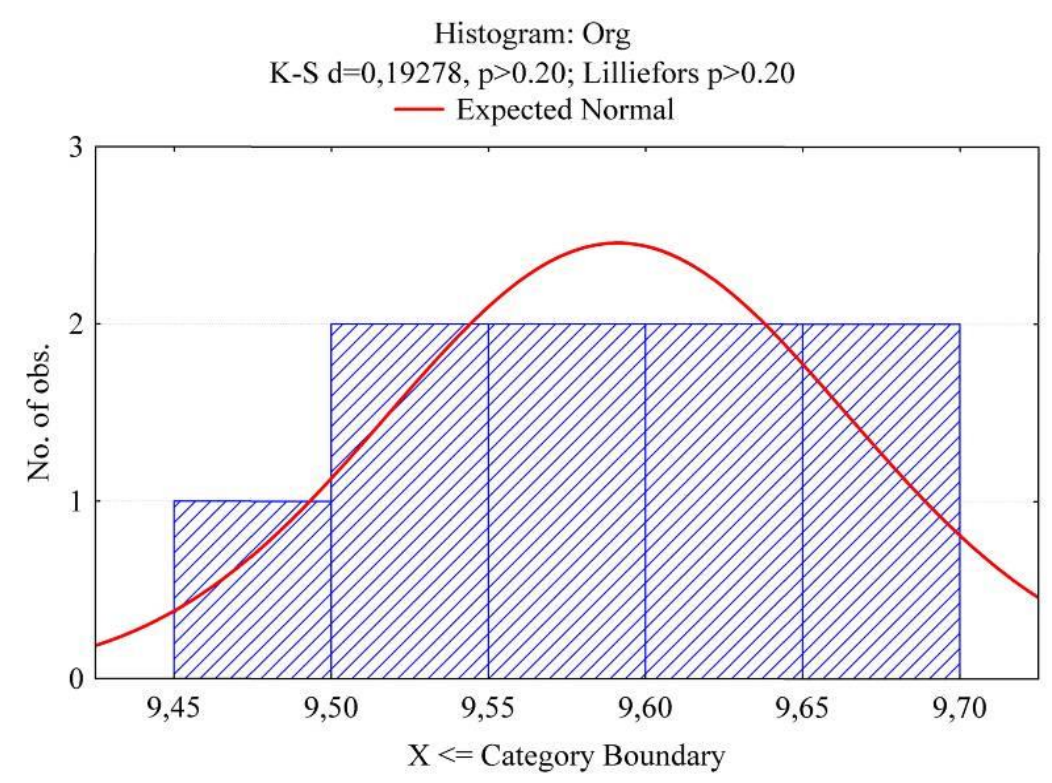

Figure 15. Histogram of the distribution of sensory evaluation (S.e.)

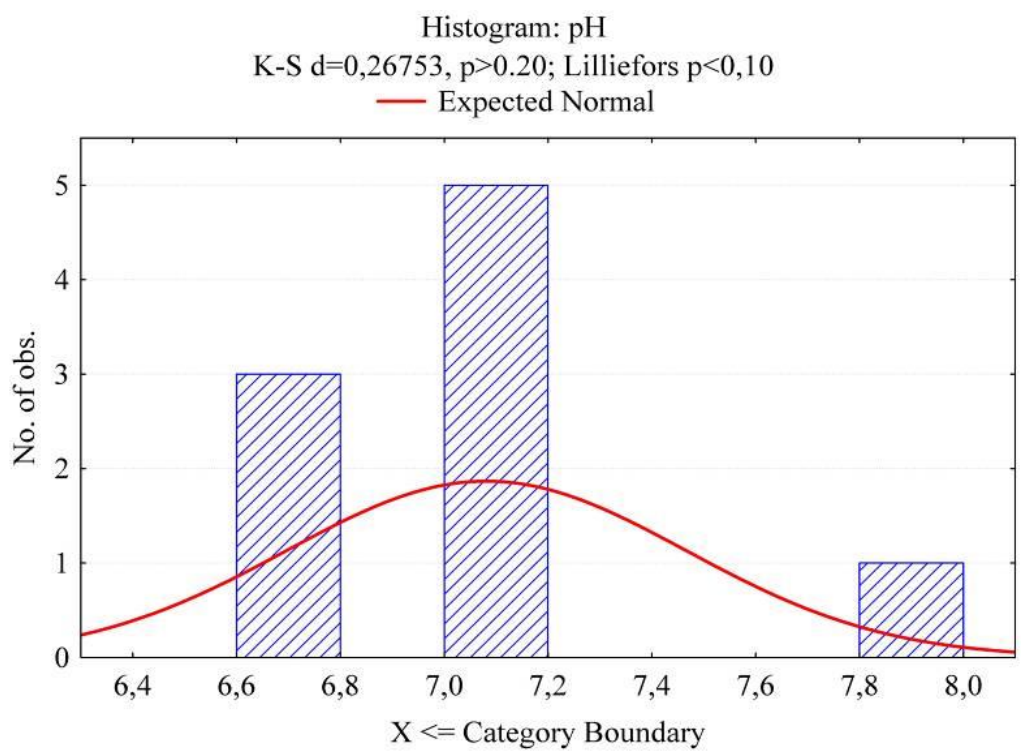

Figure 16. Histogram of the distribution of $\mathrm{pH}$ values 


\section{- Food Technology}

The histogram of the distribution of sensory evaluation is shown in Figure 15. Numerical values are divided into ranges with an interval of 0.5 , starting from 9.45 to 9.70 points. Only 5 ranges and the same number of columns. The maximum frequency is typical for 4 ranges in the range 9.50-9.70 points -8 values of the variable. The lowest frequency has the range 9.45-9.50 points, which got 1 value of the variable.

Histogram: $\mathrm{Eh}_{\min }, \mathrm{mV}$

K-S d $=0,26753, p>0.20$; Lilliefors $\mathrm{p}<0,10$

— Expected Normal

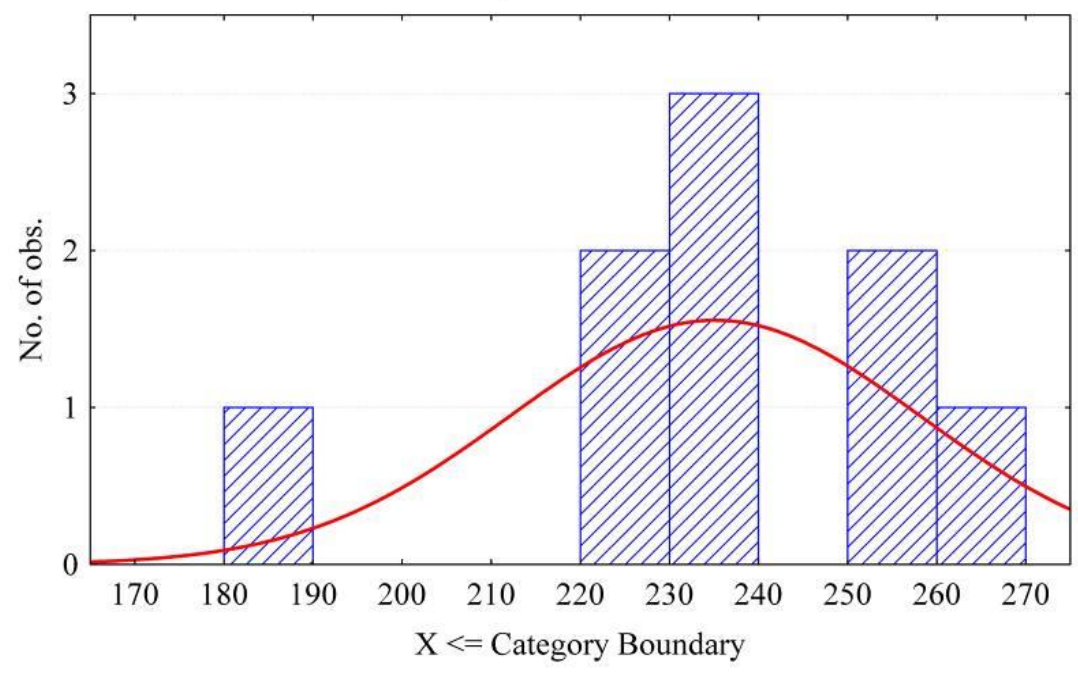

Figure 17. Histogram of the distribution of values of the level of $R P\left(E h_{\min }\right)$

Histogram: $\mathrm{Eh}_{\text {act }}$

K-S d $=0,32779, \mathrm{p}>0.20$; Lilliefors $\mathrm{p}<0,01$

— Expected Normal

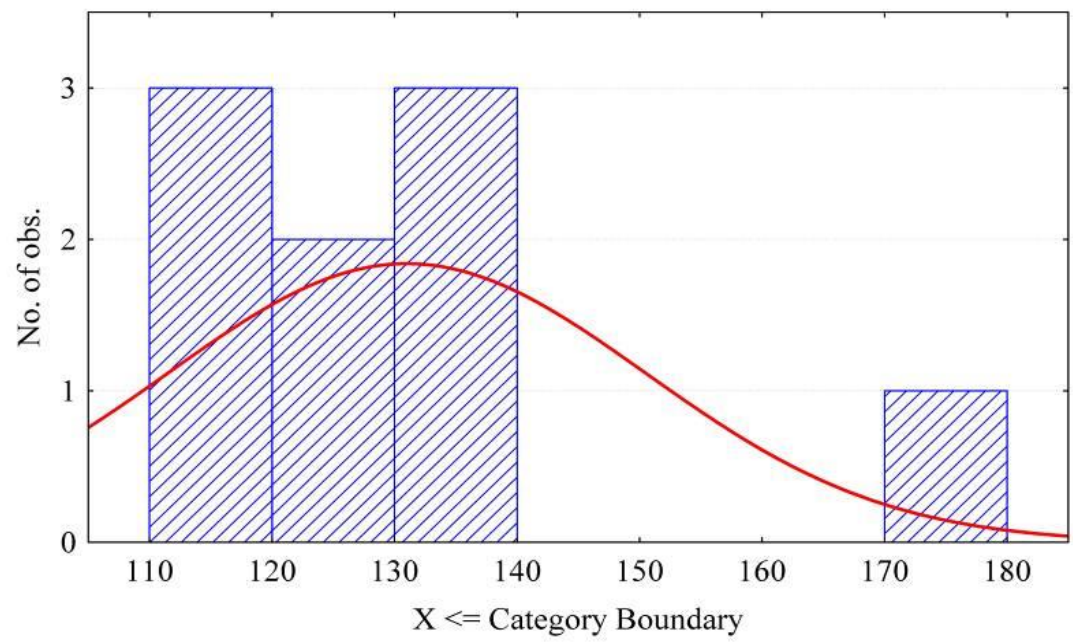

Figure 18. Histogram of the distribution of values of the level of $R P\left(E h_{a c t}\right)$ 
Figure 16 shows the distribution of $\mathrm{pH}$ values, the range of which is divided into 3 columns. It is established that 9 data elements lie in the range of $p H$ values 6.6-8.0. The highest frequency 5 is the range of $p H$ values 7.0-7.2, 3 - in the range of $p H$ values 6.6-6.8, and only $1-$ in the range $7.8-8.0$, which is the lowest frequency.

Histogram: RE

$$
\begin{gathered}
\mathrm{K}-\mathrm{S} \mathrm{d}=0,34771, \mathrm{p}<0,20 ; \text { Lilliefors } \mathrm{p}<0,01 \\
\text { Expected Normal }
\end{gathered}
$$

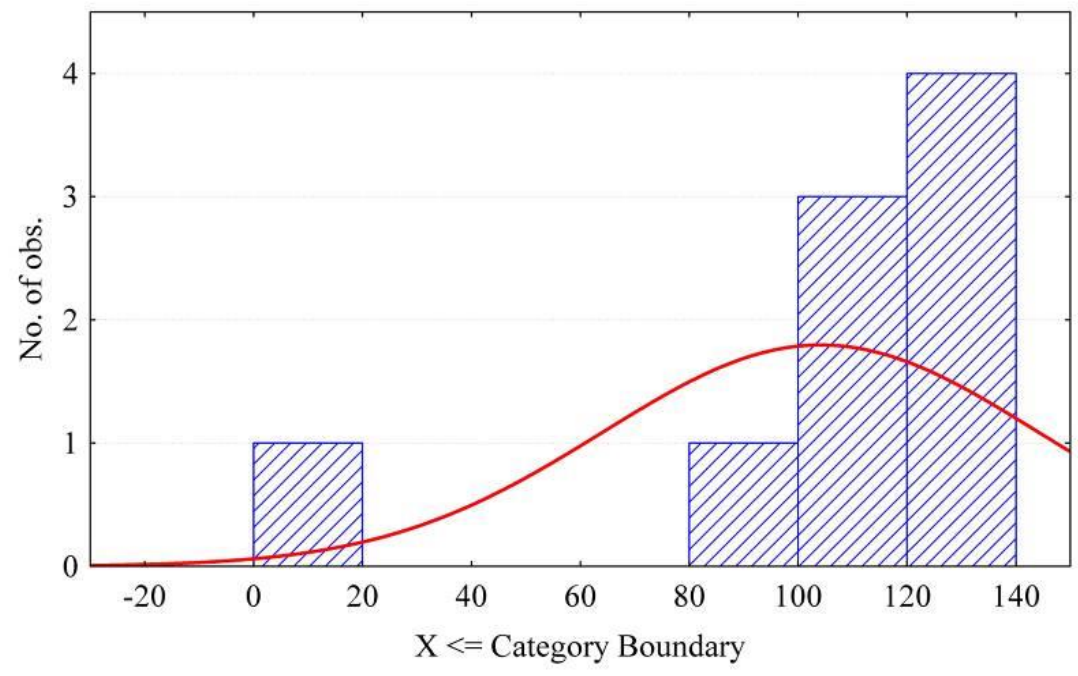

Figure 19. Histogram of the distribution of recovery energy values $(R E)$

Figure 17 shows the histogram of $R P\left(E h_{\min }\right)$. The $\mathrm{x}$-axis is divided into 5 ranges ranging from 180 to $270 \mathrm{mV}$. According to the values of the elements in the data set, only 5 columns. The maximum frequency is typical for the range $230-240 \mathrm{mV}$, which includes 3 elements. The lowest frequency is characteristic for the ranges $180-190 \mathrm{mV}, 260-270 \mathrm{mV}$, which includes 1 element.

The value of the histogram $\left(E h_{a c t}\right)$ (Figure 18) is divided into 4 ranges, starting with 110 and ending with $180 \mathrm{mV}$. The maximum repetition rate is typical for the range 110-120 mV and $130-140 \mathrm{mV}$, each includes 3 values. The lowest frequency of the ranges is $170-180$ $\mathrm{mV}$, which includes 1 element.

Figure 19 shows a histogram of $R E$, which includes 4 ranges starting from 0 to $140 \mathrm{mV}$. The maximum frequency, which consists of 4 elements, belongs to the range $120-140 \mathrm{mV}$, and the lowest $0-20 \mathrm{mV}$ and $80-100 \mathrm{mV}$, which include 1 element.

Histograms allow you to develop statistics on the frequency of values in a certain range. They are a generalized view of the data obtained during sensory evaluation and physicochemical values (Shendrik et al., 2019) [40].

Based on mathematical and statistical analysis, it was found that physicochemical parameters $\left(p H, E h_{\min }, E h_{a c t}, R E\right)$ are statistically insignificant for sensory evaluation (S.e.) and infusion temperature $(t)$. The range of values with very high correlation $(r=0.9-1.0)$ includes the following indicators: $p H, E h_{\text {min }}, E h_{a c t}, R E$. 


\section{Development of recipes of alcoholic beverages}

On the basis of the obtained results, it was established that the maximum values of $R P$ have extracts of Ruta graveolens and Nepeta transcaucasica Grossch. These extracts were used in the preparation of cocktails, the recipes of which are presented in Table 7-8.

\section{Composition of the cocktail «Mint mulled wine»}

Table 7

\begin{tabular}{|l|c|}
\hline \multicolumn{1}{|c|}{ Ingredients } & Content, \% \\
\hline Red wine & 62.65 \\
\hline $\begin{array}{l}\text { Extract of Nepeta transcaucasica } \\
\text { Grossch }\end{array}$ & 25.0 \\
\hline Sugar & 12.0 \\
\hline Nutmeg, cloves, cinnamon, allspice & 0.35 \\
\hline
\end{tabular}

Composition of the cocktail «Pomegranate grog»

Table 8

\begin{tabular}{|l|c|}
\hline \multicolumn{1}{|c|}{ Ingredients } & Content, \% \\
\hline Extract of Ruta graveolens & 27.0 \\
\hline Ginger & 0.5 \\
\hline Grenadine & 8.5 \\
\hline Lemon fresh & 14.0 \\
\hline Black tea & 50.0 \\
\hline
\end{tabular}

The data obtained are correlated with the basic scientific concepts which are displayed in the works (Kamdem et al., 2013; Frolova et al., 2019; Gerolis et al., 2017; Imark et al., 2000; Pyrzynska, Sentkowska, 2019; Wong et al., 2020; Sentkowska, Pyrzynska, 2018; Siddiqui et al., 2018; Steenkamp et al., 2004; Ruiz-Ruiz et al., 2020; Naithani et al., 2006; Buglass et al., 2012; Grunert et al., 2018; Gullón et al., 2018; Gulua et al., 2018; Joubert, Beer, 2012; Silka et al., 2016; Naumenko et al., 2015; Frolova, Korablova, 2016) [10-18, 25, 26, 30-34, 4345], regarding the processes of extracting of plant materials.

Improvement of the technology of alcoholic beverages (Andreou et al., 2018; Chandrasekara, Shahidi, 2018; Iannitti, Palmieri, 2009; Halliwell, Gutteridge, 1990; KawaRygielska et al., 2019; Fotakis et al., 2016; Vergun et al., 2018; Vergun et al., 2019; Kurylo et al., 2018) [4-9, 27-29] is due to the addition of spicy-aromatic aqueous-alcoholic infusions. It allows to increase the antioxidant properties of the product (Breiter et al., 2011; Dube et al., 2017; Keating et al., 2014; Oh et al., 2013; Herrera et al., 2018; Humia et al., 2020; Vergun et al., 2018; Vergun et al., 2019; Kurylo et al., 2018) [19-24, 27-29], will help to increase the immunity of the human body, improve the metabolism, positively affect the cardiovascular system, in addition it increases the consumer properties and will allow to reduce the cost of the finished product. 


\section{Conclusions}

1. It is established that one of the promising ways of forming consumer properties and expanding the range of alcoholic products is the use of new types of spicy-aromatic plants, which include biologically active substances. Such substances improve the sensory evaluation of beverages, contribute to the promotion of human health (antioxidant effects, enhancing redox reactions).

2. Experimental studies show that all aqueous-alcoholic infusions of aromatic origin contain antioxidant systems. It was found that the recovery value of all the tested extracts is positive and ranges from 100.0 to $138.2 \mathrm{mV}$.

3. Histograms allow you to develop statistics on the frequency of values in a certain range. They are a generalized view of the data obtained during sensory evaluation and physicochemical values.

4. Based on mathematical and statistical analysis, it was found that the infusion temperature $(t)$ has a statistically insignificant effect on physicochemical parameters $\left(p H, E h_{\min }, E h_{a c t}, R E\right)$, which have a statistically insignificant effect on sensory evaluation $(S . e$.$) . The range of values with very high correlation (r=0.9-1.0)$ includes the following indicators: $p H, E h_{\text {min }}, E h_{a c t}, R E$.

5. Improvement of the technology of alcoholic cocktails by adding spicy-aromatic aqueous-alcoholic infusions allows to increase the redox properties of the product, increases consumer properties and reduces the cost of the finished product.

\section{References}

1. Dubovkina I., Davydenko B., Rikhter V. (2019), Modelling of the hydrodynamic conditions throughout liquid system treatment by alternating impulses of pressure, Ukrainian Food Journal, 8(2), pp. 343-354.

2. Kuzmin O., Kovalchuk Y., Velychko V., Romanchenko N. (2016), Improvement technologies of aqueous-alcoholic infusions for the production of syrups, Ukrainian Journal of Food Science, 4(2). pp. 258-275.

3. Kuzmin O., Levkun K., Riznyk A. (2017), Qualimetric assessment of diets, Ukrainian Food Journal, 6(1), pp. 46-60.

4. Andreou V., Strati I.F., Fotakis C., Liouni M., Sinanoglou V.J. (2018), Herbal distillates: A new era of grape marc distillates with enriched antioxidant profile, Food Chemistry, 253, pp. 171-178.

5. Chandrasekara A., Shahidi F. (2018), Herbal beverages: Bioactive compounds and their role in disease risk reduction - A review, Journal of Traditional and Complementary Medicine, 8(4), pp. 451-458.

6. Iannitti T., Palmieri B. (2009), Antioxidant therapy effectiveness: an up to date, European Review for Medical and Pharmacological Sciences, 13, pp. 245-278.

7. Halliwell B., Gutteridge J.M.C. (1990), The antioxidants of human extracellular fluids, Archives of Biochemistry and Biophysics, 280, pp. 1-8.

8. Kawa-Rygielska J., Adamenko K., Kucharska A.Z., Szatkowska K. (2019), Fruit and herbal meads - Chemical composition and antioxidant properties, Food Chemistry, 283, pp. 1927.

9. Fotakis C., Tsigrimani D., Tsiaka T., Lantzouraki D.Z., Zoumpoulakis P. (2016), Metabolic and antioxidant profiles of herbal infusions and decoctions, Food Chemistry, 211, pp. 963 971. 


\section{Food Technology}

10. Kamdem J.P., Olalekan E.O., Hassan W., Kade I.J., Rocha J.B.T. (2013), Trichilia catigua (Catuaba) bark extract exerts neuroprotection against oxidative stress induced by different neurotoxic agents in rat hippocampal slices, Industrial Crops and Products, 50, pp. 625632.

11. Frolova N., Ukrainets A., Sylka I., Nemirich A., Kuzmin O. (2019), Separation of terpenes from lemon essential oil by selective fractionation under a vacuum, Eastern-European Journal of Enterprise Technologies, 2/11(98), pp. 32-36.

12. Gerolis L.G.L., Lameiras F.S., Krambrock K., Neves M.J. (2017), Effect of gamma radiation on antioxidant capacity of green tea, yerba mate, and chamomile tea as evaluated by different methods, Radiation Physics and Chemistry, 130, pp. 177-185.

13. Imark C., Kneubühl M., Bodmer S. (2000), Occurrence and activity of natural antioxidants in herbal spirits, Innovative Food Science \& Emerging Technologies, 1 (4), pp. 239-243.

14. Pyrzynska K., Sentkowska A. (2019), Herbal Beverages as a Source of Antioxidant Phenolics, Natural Beverages, 5, pp. 125-142.

15. Wong F.C., Xiao J., Wang S., Ee K.Y., Chai T.T. (2020), Advances on the antioxidant peptides from edible plant sources, Trends in Food Science \& Technology, 99, pp. 44-57.

16. Sentkowska A., Pyrzynska K. (2018), Investigation of antioxidant interaction between Green tea polyphenols and acetaminophen using isobolographic analysis, Journal of Pharmaceutical and Biomedical Analysis, 15910, pp. 393-397.

17. Siddiqui N.A., Al-Yousef H.M., Alhowiriny T.A., Alam P., Abdallah R.H. (2018), Concurrent analysis of bioactive triterpenes oleanolic acid and $\beta$-amyrin in antioxidant active fractions of Hibiscus calyphyllus, Hibiscus deflersii and Hibiscus micranthus grown in Saudi Arabia by applying validated HPTLC method, Saudi Pharmaceutical Journal, 26, pp. 266-273.

18. Steenkamp V., Fernandes A.C., Rensburg C.E.J., Jäger A.K. (2004), Antioxidant scavenging potential of South African export herbal teas, South African Journal of Botany, 70(4), pp. 660-663.

19. Breiter T., Laue C. Kressel G., Gröll S., Hahn A. (2011), Bioavailability and antioxidant potential of rooibos flavonoids in humans following the consumption of different rooibos formulations, Food Chemistry, 128(215), pp. 338-347.

20. Dube P., Meyer S., Marnewick J.L. (2017), Antimicrobial and antioxidant activities of different solvent extracts from fermented and green honeybush (Cyclopia intermedia) plant material, South African Journal of Botany, 110, pp. 184-193.

21. Keating L., Hayes J., Moane S., Lehane M., Furey A. The effect of simulated gastrointestinal conditions on the antioxidant activity of herbal preparations made from native Irish hawthorn. Journal of Herbal Medicine. 4(3). 2014. pp. 127-133.

22. Oh J., Jo H., Cho A.R., Kim S.J., Han J. (2013), Antioxidant and antimicrobial activities of various leafy herbal teas, Food Control, 31(2), pp. 403-409.

23. Herrera T., Aguilera Y., Rebollo-Hernanz M., Bravo E., Martín-Cabrejas M.A. (2018), Teas and herbal infusions as sources of melatonin and other bioactive non-nutrient components, LWT, 89, pp. 65-73.

24. Humia B.V., Santos K.S., Schneider J.K., Leal I.L., Padilha F.F. (2020), Physicochemical and sensory profile of Beauregard sweet potato beer, Food Chemistry, 312.

25. Ruiz-Ruiz J.C., Aldana G.C.E, Cruz A.I.C., Segura-Campos M.R. (2020), Antioxidant Activity of Polyphenols Extracted From Hop Used in Craft Beer, Biotechnological Progress and Beverage Consumption, 9, pp. 283-310.

26. Naithani V., Nair S., Kakkar P. (2006), Decline in antioxidant capacity of Indian herbal teas during storage and its relation to phenolic content, Food Research International, 39(2), pp. $176-181$.

27. Vergun O., Kačaniova M., Rakhmetov D., Shymanska O., Bondarchuk O., Brindza J., Ivanišová E. (2018), Antioxidant and antimicrobial activity of Bunias orientalis L. and 
Scorzonera hispanica L. ethanol extracts, Agrobiodiversity for Improving Nutrition, Health and Life Quality, 2, pp. 29-38.

28. Vergun O., Svydenko L., Grygorieva O., Shymanska O., Rakhmetov D., Brindza J., Ivanišová E. (2019), Antioxidant capacity of plant raw material of Scutellaria baicalensis Georgi, Potravinarstvo Slovak Journal of Food Science, 13(1), pp. 614-621.

29. Kurylo V.L., Rakhmetov D.B., Kulyk M.I. (2018), Biological features and potential of yield of energy crops of the thin-skinned family in the conditions of Ukraine, Bulletin of Poltava State Agrarian Academy, 1, pp. 11-17.

30. Buglass A.J., Caven-Quantrill D.J. (2012), Applications of natural ingredients in alcoholic drinks, Natural Food Additives, Ingredients and Flavourings, 16, pp. 358-416.

31. Grunert K.G., Hieke S., Juhl H.J. (2018), Consumer wants and use of ingredient and nutrition information for alcoholic drinks: A cross-cultural study in six EU countries, Food Quality and Preference, 63, pp. 107-118.

32. Gullón B., Eibes G., Moreira M.T., Herrera R., Gullón P. (2018), Yerba mate waste: A sustainable resource of antioxidant compounds, Industrial Crops and Products, 113, pp. 398-405.

33. Gulua L., Nikolaishvili L., Jgenti M., Turmanidze T., Dzneladze G. (2018), Polyphenol content, anti-lipase and antioxidant activity of teas made in Georgia, Annals of Agrarian Science, 16 (3), pp. 357-361.

34. Joubert E., Beer D. (2012), Phenolic content and antioxidant activity of rooibos food ingredient extracts, Journal of Food Composition and Analysis, 27(1). pp. 45-51.

35. Merwe J.D., Beer D., Swanevelder S., Joubert E., Gelderblom W.C.A. (2017), Dietary exposure to honeybush (Cyclopia) polyphenol-enriched extracts altered redox status and expression of oxidative stress and antioxidant defense-related genes in rat liver, South African Journal of Botany, 110, pp. 230-239.

36. Bahir V.M. (1999), Sovremennye tehnicheskie jelektrohimicheskie sistemy dlja obezzarazhivanija, ochistki i aktivirovanija vody, VNIIIMT.

37. Priluckij V.I. (1997), Okislitel'no-vosstanovitel'nyj potencial dlja harakteristiki protivokislitel'noj aktivnosti razlichnyh napitkov i vitaminnyh komponentov, Jelektrohim. aktivacija v medicine, sel. hozjajstve, prom-sti: I Mezhdunar. Simpozium.

38. Rakhmetov D.B. (2011), Teoretychni ta prykladni aspekty introduktsiyi roslyn v Ukrayini, Kiev: Ahrar Media Crup.

39. Hinkle D.E., Wiersma W., Jurs S.G. (2003), Applied statistics for the behavioral sciences, Boston, Mass: Houghton Mifflin.

40. Shendrik T., Levandovskyi L., Kuts A., Prybylskyi V., Karputina M. (2019), Correlation between the quality indicators of activated coal in vodka technology, Ukrainian Journal of Food Science, 7(1), pp. 33-48.

41. Prévost H., Brillet-Viel A. (2014), Ecology of bacteria and fungi in foods, Influence of Redox Potential, Encyclopedia of Food Microbiology (Second Edition), pp. 595-601.

42. Nicoli M.C., Toniolo R., Anese M. (2004), Relationship between redox potential and chainbreaking activity of model systems and foods, Food Chemistry, 88(1), pp. 79-83.

43. Silka I., Frolova N., Huts V. (2016), Kinetic model of the quality change of modern foodstuffs, Food Science and Technology, 10(1), pp. 11-15.

44. Naumenko K., Petrusha O., Frolova N., Fedorenko O. (2015), Quality assessment of extracts from unconventional plant raw materials, Eastern-European Journal of Enterprise Technologies, 4(10), pp. 49-54.

45. Frolova N., Korablova O. (2016), Scientific basis of use of fruits coriandrum sativum L. in food technologies, Potravinarstvo Slovak Journal of Food Sciences, 10(1), pp. 469-474. 